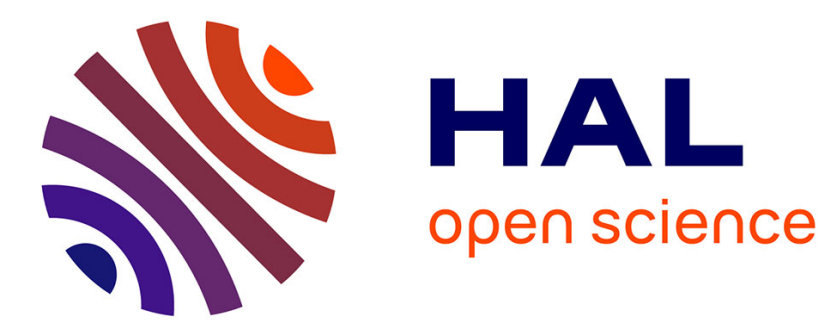

\title{
Plasma and pituary prolactin levels in rainbow trout during adaptation to different salinities
}

\author{
Patrick Prunet, G. Boeuf, Louis L. Houdebine
}

\section{To cite this version:}

Patrick Prunet, G. Boeuf, Louis L. Houdebine. Plasma and pituary prolactin levels in rainbow trout during adaptation to different salinities. Journal of Experimental Zoology, 1985, 235, pp.187-196. 10.1002/jez.1402350205 . hal-02728609

\section{HAL Id: hal-02728609 \\ https://hal.inrae.fr/hal-02728609}

Submitted on 2 Jun 2020

HAL is a multi-disciplinary open access archive for the deposit and dissemination of scientific research documents, whether they are published or not. The documents may come from teaching and research institutions in France or abroad, or from public or private research centers.
L'archive ouverte pluridisciplinaire HAL, est destinée au dépôt et à la diffusion de documents scientifiques de niveau recherche, publiés ou non, émanant des établissements d'enseignement et de recherche français ou étrangers, des laboratoires publics ou privés.

\section{다(1)(2)}

Distributed under a Creative Commons Attribution - ShareAlike| 4.0 International 


\title{
Plasma and Pituitary Prolactin Levels in Rainbow Trout During Adaptation to Different Salinities
}

\author{
P. PRUNET, G. BOEUF, AND L.M. HOUDLBINE \\ Laboratoire de Physiologie des Poissons INRA, Campus Universitaire de \\ Rennes-beaulieu, Avenue du Genéral Leclerc, 35012 Rennes Cédex, France
}

\begin{abstract}
The development of a highly specific radioimmunoassay for salmonid prolactin (PRL) using chinook salmon PRL allowed us to study plasma and pituitary PRL profiles in large sedentary rainbow trout (Salmo gairdneri) transferred from fresh water to seawater and vice versa. Plasma osmotic pressure and chloride levels were also measured for 3 weeks following change of salinity. Within 1 day after transfer to full seawater we observed a plasma PRL decrease, which stayed significantly lower $(3-5 \mathrm{ng} / \mathrm{ml})$ than the fresh water control group (10-15 $\mathrm{ng} / \mathrm{ml})$ during the entire experiment. Pituitary PRL content showed an initial abrupt increase, but after 3 weeks in seawater pituitary PRL content had decreased to the same level as in the fresh water control group. On the contrary, transfer from seawater to fresh water was followed within 1 day by a rise in plasma PRL levels, which stayed high (10-15 ng/ml) after 3 weeks in fresh water. Simultaneously, pituitary PRL content decreased significantly. These results may indicate an important role of PRL in fresh water adaptation of sedentary rainbow trout.
\end{abstract}

Since the demonstration by Pickford and Philips ('59) of the requirement for prolactin (PRL) to allow fresh water survival of hypophysectomized Fundulus heteroclitus, numerous studies have established the important role of PRL in fresh water osmoregulation by teleosts (see recent reviews by Ensor, '78; Hirano and Mayer-Gostan, '78; Clarke and Bern, '80; Loretz and Bern, '82). In salmonids, available information leads to a conflicting picture of the importance of PRL in the control of osmoregulation. Hypophysectomy of brown trout (Oduleye, '75) or rainbow trout (Donaldson and McBride, '67; Komourdjian and Idler, '77; Björnsson and Hansson, '83) does not impair survival in fresh water after recovery in one-third seawater. However, Björnsson and Hannson ('83) noticed a significant decrease of plasma chloride and ionized calcium levels after hypophysectomy and transfer to fresh water. Histological studies of pituitary PRL cells in salmonids reared in different salinities have given contradictory results. Several reports suggest that PRL might play a role in fresh water osmoregulation in coho salmon, as PRL cells appear less active after adaptation to seawater compared to fresh water (Nagahama, '73; Nagahama et al., '77; Leather- land and Lin, '75; McKeown and Hazlett, '75). However, Cook and Van Overbeeke ('69) and McKeown and Leatherland ('73) found no effect of ambient salinity on PRL cell activity in adult migatory or immature sockeye salmon.

Comparing seawater smolts to fresh water smolts, Nishioka et al. ('82) observed a moderate activity of PRL cells and suggested a possible role of PRL for osmoregulation in seawater. However, the correlation between PRL cell activity and plasma level is not always easy to establish; in addition, seasonal changes in PRL cell activity may mask any effect of exposure to different salinities (Nagahama et al., '77). Attempts to measure pituitary and plasma PRL levels using heterologous radioimmunoassays (labeled ovine PRL with antiserum to "pollack" PRL or with antiovine PRL antiserum) have given paradoxical results (Mckeown and Van $\mathrm{O}$ verbeeke, '72; Leatherland and McKeown, '74; Brewer and McKeown, '80). Moreover,

G. Boeuf's present address is IFREMER Centre Oceanologique de Bretagne, Brest, France.

L.M. Houdebine's present address is Laboratoire de Physiologie de la Lactation INRA CNRZ, Domaine de Vilvert, 78350 Jouy-en-Josas, France. 
Nicoll ('75) has questioned the validity of such radioimmunoassays and emphasized the need for extensive validation when using such heterologous systems. Obviously more information about plasma and pituitary PRL levels is needed to clarify the role of this hormone in salmonid osmoregulation. Recently, highly purified salmon PRL has been obtained from the chum salmon Onchorhynchus keta (Kawauchi et al., '83') and from the chinook salmon Onchorhynchus tschawytscha (Prunet and Houdebine, '84). Using chum PRL and a rabbit antiserum to chinook PRL, a radioimmunoassay for salmonid prolactin has been developed and validated (Hirano et al., '85). A very similar radioimmunoassay, chinook PRL with anti-chinook PRL antiserum, has been developed in our laboratory. Using this highly specific radioimmunoassay, plasma and pituitary PRL levels were followed in domesticated rainbow trout (Salmo gairdneri) directly transferred from fresh water to $100 \%$ seawater and vice versa.

\section{MATERIALS AND METHODS Transfer experiments}

A sedentary domesticated strain of rainbow trout (Salmo gairdneri) was purchased from a private hatchery in Brittany (Cornec). Nine-month-old fish were introduced in experimental frames in Brest (Centre Oceanologique de Bretagne) in October 1983. The first experiment (transfer from fresh water to seawater) began on November 21 and lasted 3 weeks (mean weight of the trouts on the day of transfer: $196.6 \pm 3.5 \mathrm{~g} ; \mathrm{N}=100$ ). The transfer was achieved by switching off the fresh water tap and by switching on the seawater tap. In this manner, seawater replaced fresh water within $2 \mathrm{hr}$ and handling stress was avoided. Sixty fish were kept in fresh water as a control. The water temperature during the experiment decreased slightly (fresh water: 12 to $9.5^{\circ} \mathrm{C}$; seawater: 11 to $9^{\circ} \mathrm{C}$ ) and the difference in temperature between fresh and seawater on the day of transfer was $1^{\circ} \mathrm{C}$. The salinity of the seawater stayed constant $(35 \pm 0.5 \mathrm{~g} / \mathrm{l} \mathrm{NaCl})$ during the experiment. Both groups were starved for 3 days before transfer. On the first day of the experiment, trout kept in fresh water fed as usual, while trout in seawater accepted food only from day 4 until the end of the experiment. On the day of transfer, a sample of ten fish, representative of the whole population in fresh water, was taken from the control group. Thereafter, the sampling protocol was as indicated in Figure 2.
Half of the animals in the original stock (not used in the first experiment) were transferred on November 21 into full seawater until March 1984. The second experiment (transfer from seawater to fresh water) was started on March 19 and lasted for 3 weeks (mean weight of the trout: $425.0 \pm 12.5 \mathrm{~g} ; \mathrm{N}$ $=100$ ). This transfer was carried out following the same feeding and sampling protocol as for the first experiment. Water temperature during the second experiment increased slightly from 9 to $13^{\circ} \mathrm{C}$ in both fresh water and seawater. All experiments were conducted under natural photoperiod $\left(48^{\circ} \mathrm{N}\right.$ latitude).

\section{Plasma collection and measurements}

After catching each trout with a hand-net the fish were quickly killed and bled (within $1 \mathrm{~min}$ ). Blood was collected from the posterior aorta always at the same time of the day between 10 and 11 AM. Plasma was collected after blood centrifugation and frozen at $-20^{\circ} \mathrm{C}$ in aliquots. Osmotic pressure was measured with a Roebling osmometer (mOsm $\mathrm{l}^{-1}$ ) and chloride level by argentimetric titration using a Radiometer chloridometer $(\mathrm{mEq}$ $1^{-1}$ ). The sexes of all the fishes were checked. All results are given in the form of mean values \pm standard errors.

\section{Radioimmunoassay}

\section{Sources of hormones and antisera}

Chinook salmon PRL was purified according to the procedure described by Prunet and Houdebine ('84). Antiserum against chinook PRL was generated in rabbits using the technique described in Hirano, et al. ('85). Ovine PRL (oPRL-15) and ovine GH (NIH-GH-S11) were supplied by the N.I.A.M.D.D. Salmon GTH was provided by Dr. B. Breton (Laboratoire de Physiologie des Poissons INRA).

\section{Iodination and radioimmunoassay procedure}

Highly purified prolactin was iodinated according to the lactoperoxidase method described by Hirano et al. ('85). The doubleantibody radioimmunoassay developed in this laboratory followed the procedure given by Hirano et al. ('85) with some modifications. Briefly, in plastic assay tubes, $50 \mu \mathrm{l}$ of standard (chinook salmon prolactin) or unknown sample were added to $50 \mu$ l of RIA buffer containing $0.02 \mathrm{M}$ phosphate buffer (pH 7.4), $0.15 \mathrm{M} \mathrm{NaCl}, 1 \%$ BSA, $0.1 \%$ triton $\mathrm{X} 100,0.1 \%$ gelatin, and $0.1 \%$ merthiolate. In addition, $100 \mu \mathrm{l}$ chinook salmon prolactin antiserum diluted 1:100,000 (unless other- 
wise specified) in a medium consisting of 0.02 M phosphate buffer ( $\mathrm{pH} 7.4$ ), 5mM EDTA, $0.1 \%$ gelatin, $0.1 \%$ merthiolate, $0.15 \mathrm{M} \mathrm{NaCl}$, and $1 \%$ normal rabbit serum. After $24 \mathrm{hr}$ of incubation at room temperature, $100 \mu \mathrm{l}$ of iodinated chinook salmon PRL, diluted in the RIA buffer $(10,000 \mathrm{cpm} /$ tube), was added to each tube and incubation continued for an additional $24 \mathrm{hr}$. Separation of bound from free hormones was accomplished by incubat. ing the reaction mixture at room tempera. ture with $200 \mu 1$ of sheep antirabbit antiserum diluted $1: 10$ in $9 \%$ polyethylene glycol solution containing $0.02 \mathrm{M}$ phosphate buffer (pH 7.4), $5 \mathrm{mM}$ EDTA, $0.15 \mathrm{~N} \mathrm{NaCl}$, $0.1 \%$ merthiolate, and $0.1 \%$ gelatin. After 3 $\mathrm{hr}$ the tubes were centrifuged for $45 \mathrm{~min}$ at $2,000 \mathrm{~g}$ and the supernatant decanted. The radioactivity was measured in Packard autogamma counter.

Plasma from hypophysectomized coho salmon was generously provided by R.S. Nishioka and Prof. H.A. Bern (University of California, Berkeley). Hypophysectomy was performed according to the technique described by Hirano, et al. ('85).

\section{Statistical analysis}

Differences between groups were tested by one-way variance analysis or by Student's t test. Significance was accepted at the $5 \%$ level.

\section{RESULTS \\ Chinook salmon prolactin radioimmunoassay}

The salmon prolactin radioimmunoassay developed in our laboratory was able to measure plasma and pituitary prolactin levels in rainbow trout. The serial dilution curves obtained with rainbow trout, atlantic salmon, and coho salmon plasma samples or rainbow trout and chinook salmon pituitary extracts were shown to be parallel to the standard curve (Fig. 1). No cross reactivity was found with plasmas from hypophysectomized coho salmon (Oncorhynchus kisutch) nor with nonsalmonid hormone preparations (ovine PRL, ovine GH or salmon GtH). The sensitivity of the assay was estimated to be $20 \mathrm{pg}$ of chinook PRL per $100 \mu 1$ assay buffer $(\mathrm{N}=4)$. The estimation of the intraassay coefficient of variation was $12.9 \%$ for a level of $3.13 \mathrm{ng} / \mathrm{ml}(\mathrm{N}=10)$ and $4.7 \%$ for a level of $11.88 \mathrm{ng} / \mathrm{ml}(\mathrm{N}=10)$. The interassay coefficient of variation was estimated to be $16 \%$ for a plasma level of $9.58 \mathrm{ng} / \mathrm{ml}(\mathrm{N}=10)$.
Recovery experiments were conducted by measuring salmon prolactin added in increasing concentration to $50 \mu 1$ trout plasma. To obtain full recovery of the salmon prolactin added (average recovery: 110\%) it was necessary to correct each radioactivity measurement obtained for an unknown sample using plasma blank tubes (3-5\% total radioactivity) rather than buffer blank tubes (2$3 \%$ total radioactivity). In all subsequent assays, this correction was done when calculating plasma prolactin concentration, whereas such a correction was not necessary for pituitary prolactin measurements.

\section{Transfer from fresh water to seawater}

Within $7 \mathrm{hr}$ after direct transfer of rainbow trout to $100 \%$ seawater, plasma osmotic pressure and $\mathrm{Cl}^{--}$concentrations started increas. ing abruptly reaching maxima on the second day. However, a decrease of these plasma parameters was observed 7 days after transfer. After 2 weeks the plasma osmotic pressure and $\mathrm{Cl}^{-}$level reached their seawater values and remained stable, indicating that the fish were able to regulate their hydromineral balance (Fig. 2).

Plasma PRL levels in rainbow trout directly transferred to seawater (Fig. 3) were already decreased after $7 \mathrm{hr}$ and reached a low basal level of $3.6 \mathrm{ng} / \mathrm{ml} 1$ day after transfer (highly significantly different from the initial PRL level; $P<0.01$ ). Plasma PRL stayed at this low level during the whole experiment. In the control group kept in fresh water, PRL levels were significantly higher than in the transferred group during the whole experimental period $(P<0.01)$. However a significant $(\mathrm{P}<0.01)$ decrease was observed between day 0 and day 4 in this group. From day 4 to the end of the experimont PRL levels measured at four different times did not vary significantly in fresh water $(P=0.05)$. During this transfer experiment each group of fish was homogeneous in size (intragroup coefficient of variation < $6 \%$ ) and the growth of the fish during the 3 week experiment was low (initial mean weight: $198.5+7.7 \mathrm{~g}$; final mean weight in fresh water: $219.6 \pm 3.2 \mathrm{~g}$; in seawater: 229.7 $\pm 7.4 \mathrm{~g} ; \mathrm{N}=10$ ). Considering the homogeneity in the size of the fish sampled it was possible to compare prolactin content per pituitary in the different groups without introducing error in the analysis. Results of pituitary prolactin content are shown in Fig. ure 3 . Within 2 days after transfer there was a highly significant increase in PRL content $(\mathrm{P}<0.01)$. This rise was followed by a less 


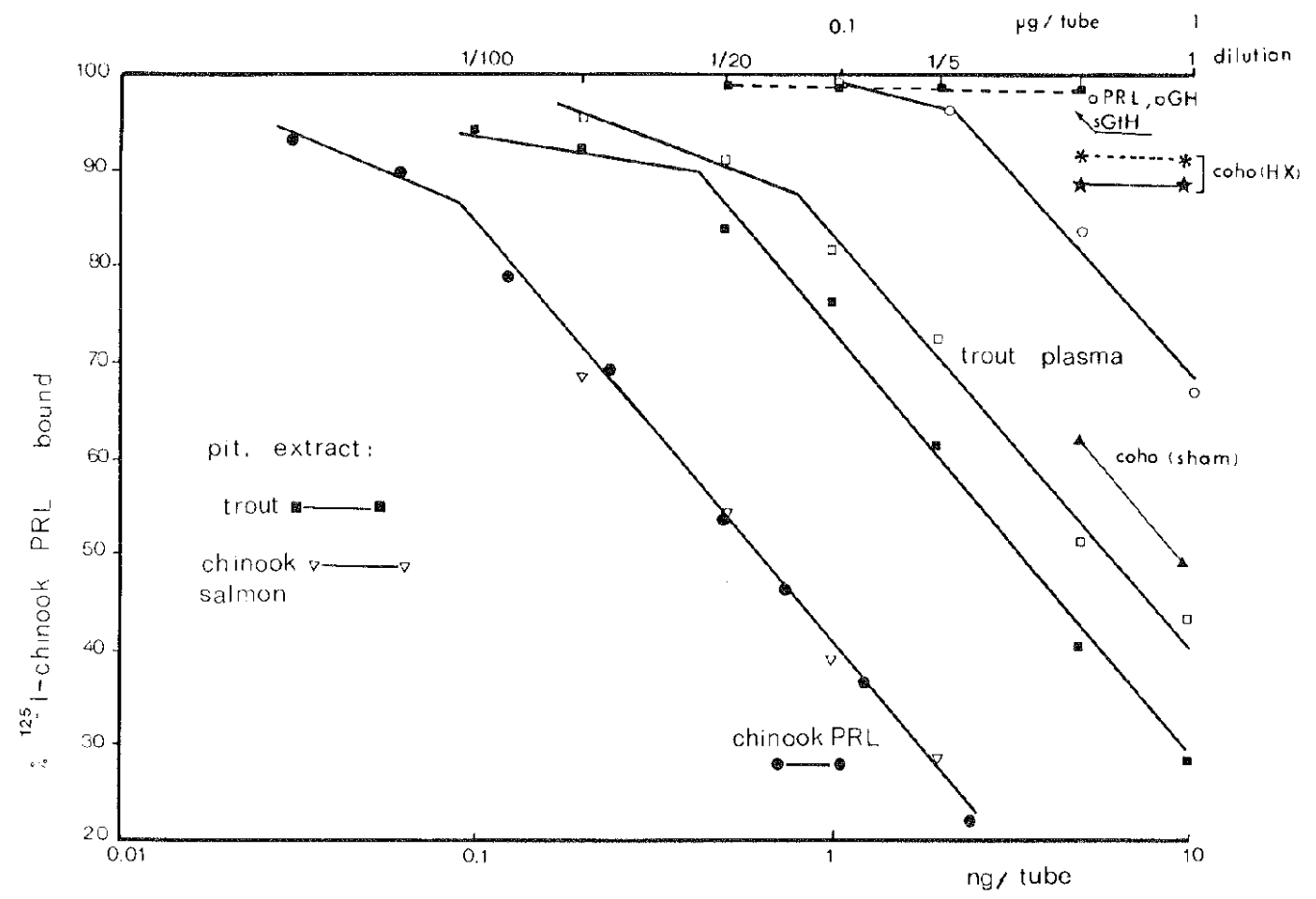

Fig. 1.-Dose-response curves for chinook PRL (standard curve) and different hormonal preparations (ovine PRL-oPRL-ovine GH-oGH-, salmon GTH-sGTH-); serial dilution of $50 \mu \mathrm{l}$ plasma from fresh water adapted rainbow troul, allantic salmon, sham-operated and hypophy-

abrupt decrease in pituitary PRL content (the PRL level on day 2 was significantly different from the PRL level on day $15(\mathrm{P}<0.05)$ and on day $21(\mathrm{P}<0.01)$. In the control group kept in fresh water there was no significant modification in pituitary PRL content. Comparison of fresh water and seawater trout on the same date showed a higher PRL content in seawater fish on day $4(\mathrm{P}<0.05)$ but no difference on days 7, 15, or 21 (Fig. 3).

\section{Transfer from seawater to fresh water}

Rainbow trout transferred from seawater to fresh water were able to regulate their hydromineral balance within 2 days as shown in Figure 4. After an initial decrease during the 2 first days, plasma osmotic pressure and $\mathrm{Cl}^{-}$levels stabilized to their fresh water values, which were significantly $(\mathrm{P}<$ 0.05 ) lower than the values measured in the control group kept in seawater on the same date (Fig. 4).

The plasma prolactin profile during this transfer experiment is shown in Figure 5. sectumized coho salmon; and serial dilution of pituitary extracts from chinook salmon (protein concontration: $1.88 \mu \mathrm{g} / \mathrm{ml}$ ) and rainhow trout (protein concentration: $0.39 \mu \mathrm{g} / \mathrm{ml})$. Each point represents the average of duplicate determination.

One day after transfer we observed a significant increase in prolactin levels $(\mathrm{P}<0.01)$ which reached a plateau after 4 days and stayed at these high levels (10-14 ng/ml) until the end of the experiment (PRL levels on days $4,7,15$, and 21 were not significantly different). In the control group kept in seawater PRL stayed low during the whole experiment and was significantly lower than in the transferred group $(P<0.01)$. Figure 5 also shows variation in pituitary prolactin content. PRL decreased significantly $(\mathrm{P}<$ 0.01 ) from an initial of $4.8 \mu \mathrm{g}$ sPRL/pituitary to $1 \mu \mathrm{g}$ sPRL/pituitary within 2 days. During the rest of the experiment pituitary PRL remained low (1-2 $\mu \mathrm{g}$ sPRL/pituitary) and without significant fluctuation. Surprisingly, pituitary PRL content in the control group kept in seawater decreased significantly ( $\mathrm{P}$ $<0.01$ ) from $4.8 \mu \mathrm{g} \mathrm{sPRL} /$ pituitary to 1.83 $\mu \mathrm{g}$ sPRL/pituitary 4 days after transfer. This decrease was followed by a slow increase, although pituitary PRL contents after day 4 were not significantly different $(P=0.05)$. 

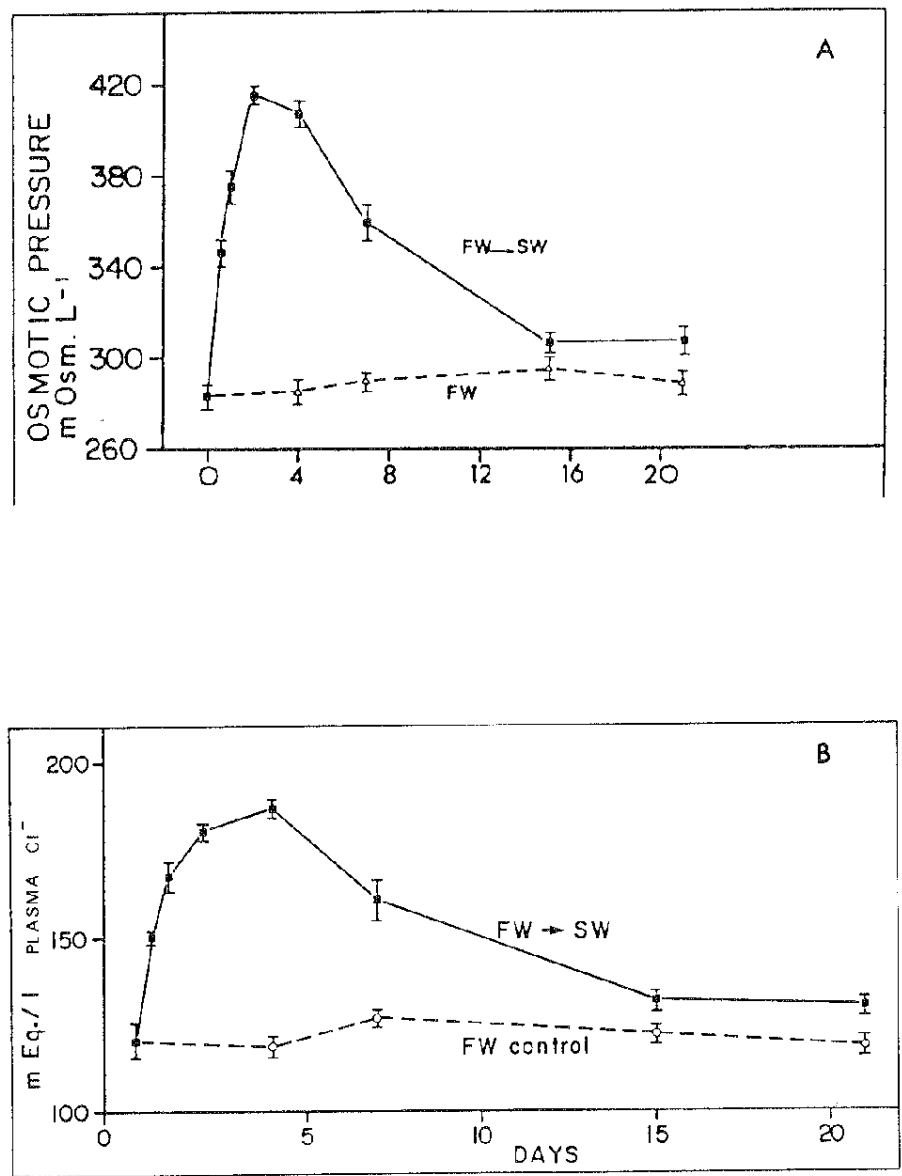

Fig. 2.-Change in plasma osmotic pressure (A) and $\mathrm{Cl}^{-}$level (B) of rainbow trout transferred from fresh water to seawater or kept in fresh water. Vertical bars represent standard errors of the mean $(\mathrm{N}=10)$.
Comparison between fresh water and seawater PRL contents showed no significant differences 4 and 7 days after transfer; however, after long term adaptation (2 and 3 weeks) the seawater group had a significantly higher pituitary PRL content than the fresh water group $(\mathrm{P}<0.05)$.

\section{DISCUSSION}

The chinook salmon PRL radioimmunoassay developed in our laboratory appears to be highly specific and suitable for measurement of PRL in plasma and pituitaries of salmonids. Pituitary extracts from eel and carp (data not show) and different hormonal preparations (ovine PRL, ovine GH, salmon $\mathrm{GtH})$ did not cross react in the assay, con- firming the narrow immunological specificity of the antichinook PRL antibody; thus, this radioimmunoassay appears to possess the same properties as the assay developed by Hirano et al. (1985) using chum PRL and antichinook PRL antibody. This is in agreement with the observation by Hirano et al. (1985) that the antichinook antiserum did not distinguish between chum PRL and chinook PRL. The sensitivity and the precision of the assay allow measurement of endogenous hormone in $50 \mu \mathrm{l}$ of trout plasma with an estimated variability (inter- and intraassay) that can be compared favorably to other radioimmunoassays developed for fish hormones (Nicoll et al., '81; Cook et al., '83; Hirano et al., '85). The most significant find. 

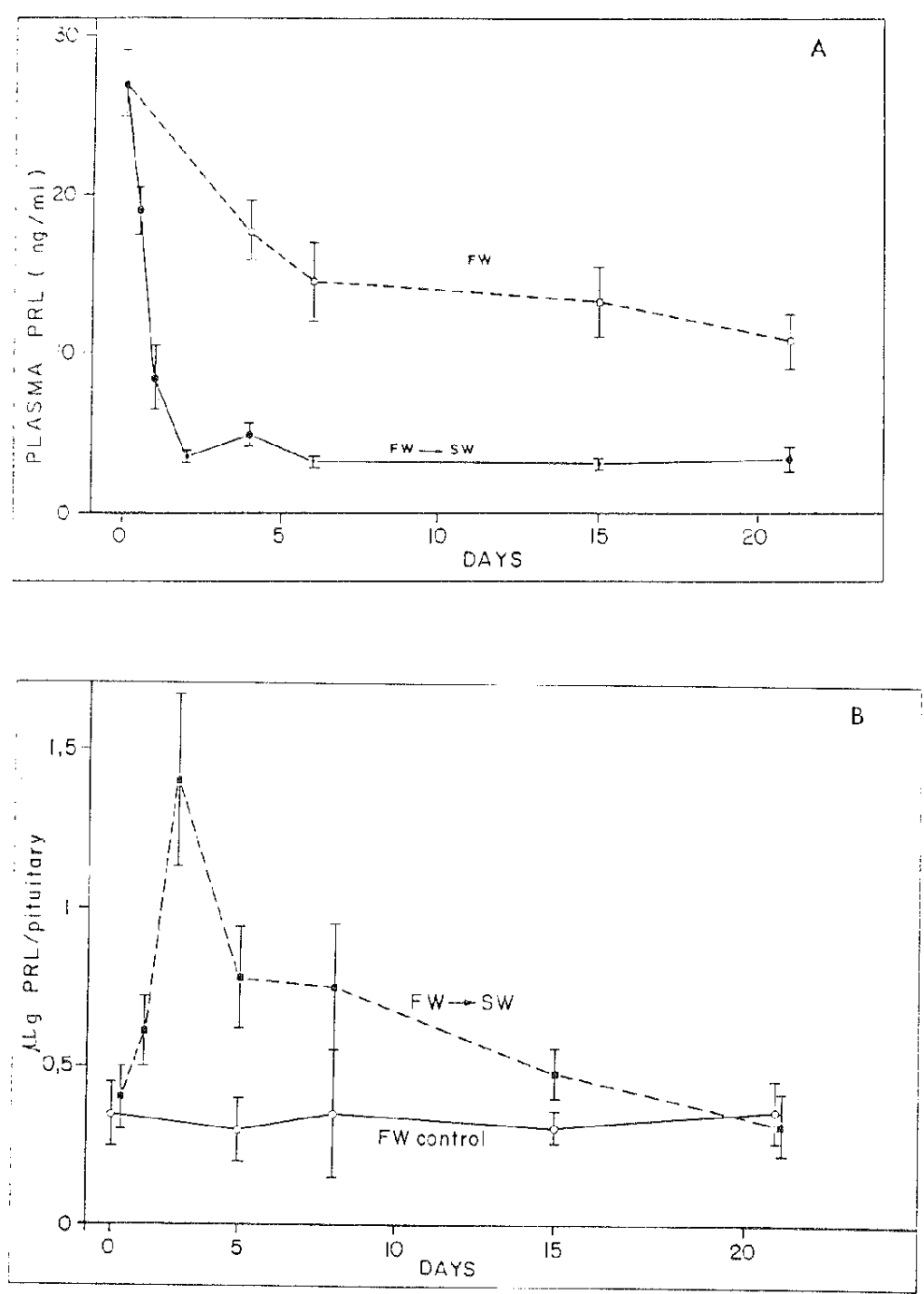

Fig. 3.-Change in plasma PRL level (A) and pituitary PRL content (B) of rainbow trout transferred from fresh water to seawater or kept in fresh water. Vertical bars represent standard errors of the mean $(N=10)$. ing of our study was the higher plasma PRL levels measured in fresh water trout compared to those of fish transferred and adapted to seawater. In our seawater transfer experiment, large size rainbow trout were able to withstand abrupt transfer and to adapt within 2 weeks to seawater. Such a pattern of adaptation of rainbow trout is in agreement with similar studies (Houston, '59; Bath and Eddy, '79; Jackson, '81; Perry and Heming, '81; Boeuf and Harache, '84). Transfer of rainbow trout from seawater to fresh water led to a small transitory osmotic pressure disequilibrium and after 2 days the fish were able to control their hydromineral balance. It is interesting to note that after each transfer to a new medium, plasma PRL changed abruptly and reached its new level within a few days, thereafter remaining stable until the end of the experiment ( 3 weeks). Moreover, plasma PRL levels in seawater trout were always low $(1-4 \mathrm{ng} / \mathrm{ml})$ even when pituitary prolactin content was high (experiment 2 , Fig. 5). In this respect, rainbow trout 

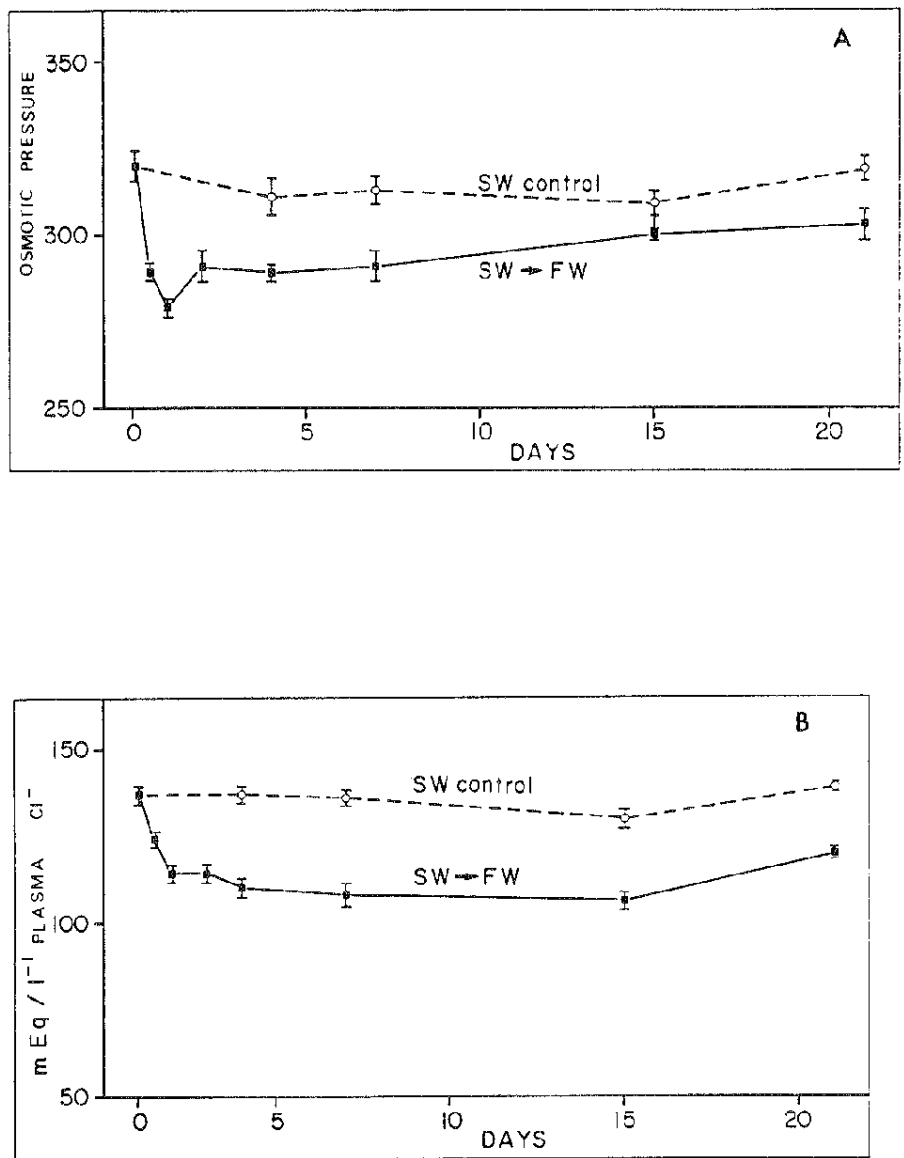

Fig. 4. - Change in plasma osmotic pressure (A) or $\mathrm{Cl}^{-}$ level (B) of rainbow trout transferred from seawater to fresh water or kept in scawater. Vertical bars represent standard errors of the mean $(\mathrm{N}=10)$. appears similar to another euryhaline species, Oreochromis mossambicus, in which plasma PRL levels have been shown, by means of homologous radioimmunoassay, to be lower in seawater (Nicoll et al., '81). These results are consistent with a large body of evidence indicating an important role of PRL in fresh water osmoregulation in teleosts (Hirano and Mayer-Gostan, '78; Clarke and Bern, '80; Loretz and Bern, '82). Using a heterologous radioimmunoassay, Leatherland and McKeown ('74) found an increase in plasma PRL levels after transfer of sockeye salmon smolts to seawater. Similarly Brewer and McKeown ('80) reported a decrease in plasma PRL levels, measured with the same technique, after transfer of seawater acclimated coho salmon into fresh water. However, the validity of such heterologous radioimmunoassays for plasma PRL has been questioned (Nicoll, '75; Nicoll et al., '81). Using a highly specific salmon prolactin radioimmunoassay, Hirano et al. ('85) found an increase in plasma PRL levels after transfer of mature fernale chum salmon from seawater to fresh water; however, no change was detected in males during the same transfer. In our fresh water transfer experiment, performed about 7 months before the spawning period, no discernible differences were found between the prolactin levels of males and females. Although this discrepancy is difficult to explain, it should be noted that the experiments reported by Hirano and colleagues were carried out on a migratory salmonid species (chum salmon) just before spawning.

Measurement of pituitary PRL content also gave interesting results. During the first 2 days after direct transfer to seawater, we 

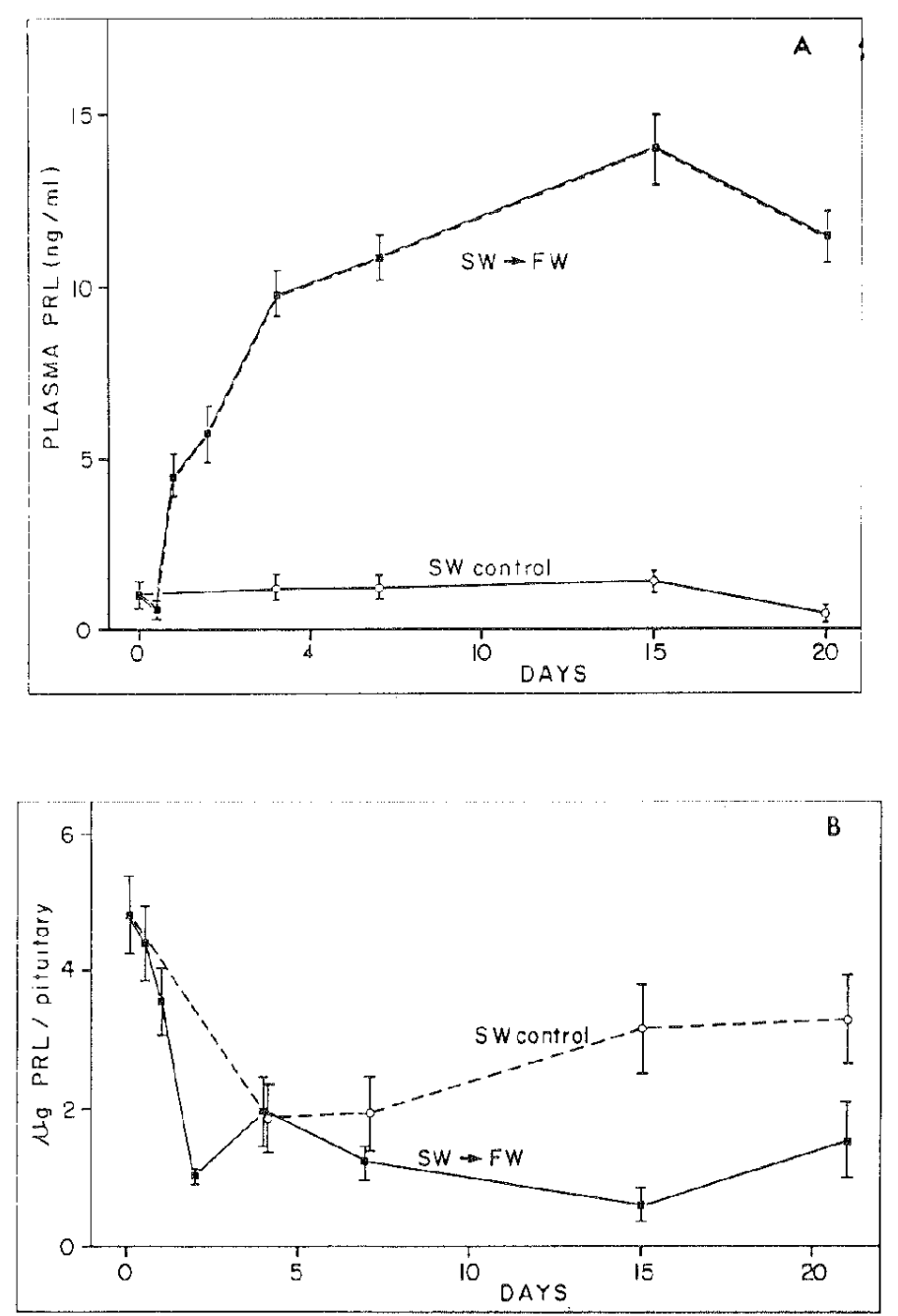

Fig. 5.--Change in plasma PlRL level (A) and pituitary PRL content (B) of rainbow trout transferred from sea-

observed an increase of pituitary PRL content (Fig. 3). On the contrary, after direct transfer of trout into fresh water a decrease of pituitary PRL content was shown (Fig. 5). Associated with abrupt modifications of plasma osmotic pressure (Figs. 2, 4), these results are consistent with a possible effect of osmotic pressure on pituitary PRL release as shown by numerous studies in fish (for reviews see Clark and Bern, '80; Specker et al., '84; Bern, '83) and confirmed in rainbow trout by in vitro experiments (Ingleton, et al., '73; Leatherland and Lin, '76). After a few days in seawater, trout showed a slow water to fresh water or kept in seawater. Vertical bars represent standard errors of the mean $(\mathrm{N}=10)$.

decrease in pituitary PRL content, which reached the level measured in the fresh water control group within 3 weeks. This decrease of pituitary PRL content was associated with a low level of plasma PRL, which could suggest a decrease in PRL cell activity during adaptation to seawater. Although several histological studies have shown an inactivation of PRL cells in salmon smolts transferred to seawater (Leatherland and McKeown, '74; McKeown and Hazlett, '75; Nagahama et al., '77), conclusions from our data on the effect of osmotic pressure on PRL cell activity should be taken with caution. In 
the second experiment, it was not possible to show a clear activation of PRL cells after transfer to fresh water.

Unexpectedly, in the fresh water to seawater transfer experiment, plasma PRL levels showed an initial decrease in the control group kept in fresh water. The only parameter that changed in this group was modification of feeding. It is conceivable that starvation prior to transfer resulted in an increase of plasma PRL, which was suppressed when the fish fed again. In the seawater to fresh water transfer experiment, such modification of plasma PRL levels was not apparent in the control group kept in seawater. However, an unexpected decrease in pituitary PRL content in this group was observed between day 0 and day 4 . Obviously, more information is needed to clarify the effect of short-term starvation in fresh water or seawater adapted rainbow trout. It is also interesting to note that the PRL pituitary content in seawater adapted trout in March was much higher than that in the trout adapted for 3 weeks to seawater 3 months earlier. These unexpected higher values might be due simply to the increase of body weight. However, since in March the fish had begun their first reproductive cycle (this strain of trout was supposed to spawn in October), such an increase in pituitary PRL content might be associated with reproduction (see Clarke and Bern, '80; Ensor et al., '84; Edery et al., '84).

In conclusion, our study has shown that, during the adaptation of sedentary rainbow trout to seawater or to fresh water, there were concomitant changes in plasma and pituitary PRI, levels. Moreover it appears that development of hypoosmoregulatory activity is associated with low plasma PRL levels, whereas hyperosmoregulatory activity is associated with high levels of plasma PRL. By contrast, Prunet and Boeuf ('85) reported plasma PRL levels that were not significantly different between fresh water and seawater adapted atlantic salmon smolts. Although our results may indicate in rainbow trout an important role of PRL in fresh water osmoregulation, further studies using hypophysectomized fish are needed to confirm the osmoregulatory role of PRL in salmonids.

\section{ACKNOWLEDGMENTS}

The authors wish to express their appreciation to M. Ollitrault and A. Leroux, who gave indispensable technical assistance; to
Dr. A. Fostier and Dr. P. Copeland, who critically reviewed the manuscript; and to $P$. Provost, who typed the manuscript. This work was supported by a NATO grant.

\section{LITERATURE CITED}

Bath, R.N., and F.B. Eddy. (1979) Ionic and respiratory regulation in rainbow trout during rapid transfer to seawater. J. Comp. Physiol., 134:351-357.

Bern, H.A. (1983) Functional evolution of prolactin and growth hormone in lower vertebrates. Am. Zool., 23:663-671.

Björnsson, B.T., and T. Hansson (1983) Effects of hypophysectomy on the plasma ionic balance in rainbow trout. Salmo gairdneri. Gen. Comp. Endocrinol., 49:240-247.

Boeuf, G., and Y, Harache (1984) Adaptation à l'eau de mer de diverses especces (Salmo trutta, Salvenius fontinalis, Salmo gairdneri) et hybrides de Salmonidés (Salmo trutta $\times$ Salvenius fontinalis). Aquaculture. 40:343 358 .

Brewer, K.J., and B.A. McKeown (1980) Prolactin regulation in the coho salmon, Oncorhynchus kisutch. J. Comp. Physiol., 140:217-225.

Clarke, W.C., and H.A. Bern (1980) Comparative endocrinology of prolactin. Horm. Protcins Peptides, 8:105197

Cook, H., and A.E. van Overbeeke (1969) Ultrastructure of the eta cells in the pituitary gland of adult migratory sockeye salmon (Oncorhynchus nerka). Can. J. Zool., 47:937-941.

Cook, A.F., S.W. Wilson, and R.E. Peter (1983) Develop ment and validation of a carp growth hormone radioimmunoassay. Gen. Comp. Endocrinol., 50:335-347.

Donaldson, E.M., and J.R. McBride (1967) The effects of bypophysectomy in the rainbow trout, Salmo gairdneri (Rich) with special reference to the pituitary interrenal axis. Gen. Comp. Endocrinol., 9:93-101.

Edery, M., G. Young, H.A. Bern, and S. Steiny (1984) Prolactin receptors in Tilapia (Sarotherodon mossam bicus) tissues: Binding studies using $125 \mathrm{I}$ labeled ovine prolactin. Gen. Comp. Endocrinul., 56:19-23.

Ensor, D.M. (1978) Comparative Endocrinology of Prolactin. Chapman and Hall. London, Chapman and Hall.

Ensor, D.M. S. Sahai, J.A.C. Lee, and 1). Tinsley (1984) Reproductive role of prolactin in fish. Gen. Comp. Endocrinol. 53(Abstract):435.

Hirano, T, and N. Mayer-Gostan (1978) Endocrine control of osmoregulation in fish. In: Comparative Endocrinology. P.J. Gaillard and H.H. Boer, eds) Elsevier Vorth Holland, Amsterdam, pp. 209-212.

Hirano, T., P. Prunet, H. Kawauchi, A. Takahashi, J. Kubota, R.S. Nishioka, H.A. Bern, K. Takada, and S. Tshii (1985) Development and validation of a salmon prolactin radioimmunoassay. Gen. Comp. Endocrinol.: (in press).

Houston, A.H. (1959) Osmoregulatory adaptation of steelhead trout to seawater. Can. J. Zool, 37:729 748.

Ingleton, P.M., B.I. Baker, and J.N. Ball (1973) Secretion of prolactin and growth hormone by teleost pituitaries in vitro. 1 . Effect of sodium concentrations and osmotic pressure during short-term incubations. J. Comp. Physiol, 87:317-328.

Jackson, A.J. (1981) Osmotic regulation in rainbow trout (Salmo gairdneri) following transfer to sca water. Aquaculture, 24:143-15̃1.

Kawauchi, H., K. Abe, A. Takahashi, T. Hirano, S. Hasegawa, N. Naito, and Y. Nakai, (1983) Isolation and properties of chum salmon prolactin. Gen. Comp. Endocrinol, 49:446-458.

Komourdjian, M.P., and D.R. Idler (1977). Hypophysec- 
tomy of rainbow trout, Salmo gairdneri and its effect on plasmatic sodium regulation. Gen. Comp. Endocrinol., 32:536-542.

Leatherland, J.F., and B.A. McKeown (1974) Effect of ambient salinity on prolactin and growth hormone secretion and on hydromineral regulation in kokanee salmon smolts (Oncorhynchus nerka). J. Comp. Phy. siol., 89:215-226.

T,eatherland, J.F., and L. Lin (1975) Activity of the pituitary gland in embryo and larval stages of coho salmon. Oncorhynchus kisutch. Can J. Zool., 53:297-310.

Leatherland, J.F., and L. Lin (1976) Fine structure of the rostral pars distalis follicle cells in homotransplanted pituitaries of rainbow trout. Salmo gairdneri. Can J. Zool., 54:122-132.

Loretz, C.A. and H.A. Bern (1982). Prolactin and osmoregulation in vertebrates. Neuroendocrinology, 35:292304.

McKeown, B.A., and C.A. Hazlett (1975). Uptake of tritiated leucine by the prolactin cell follicles of the coho salmon, Oncorhynchus kisulch. Can. J. Zool., 53:11951200.

McKeown, B.A., and A.P. Overbeeke (1972) Prolactin and growth hormone concentrations in the serum and pituitary gland of adult migratory sockeye salmon ( $\mathrm{On}$ corhynchus nerka). J. Fish. Res. Board Can., 29:303309.

McKeown, B.A., J.F. Leatherland (1973) Fine structure of the adenohypophysis in immature sockeye salmon, Oncorhynchus nerka. Z. Zellforsch Mikrosk. Anat, 140:459-471.

Nagahama, Y. (1973) Histu-physiological studies on the pituitary gland of some teleost fishes, with special reference to the classification of hormone-producing cells in the adenohypophysis. Mem. Fac. Fish. Hokkaido Univ., 21(1): 2-55.

Nagahama, Y., W.C. Clarke, and W.S. Hoar (1977) Influence of salinity on ultrastructure of the secretory cclls of the adenohypophyseal pars distalis in yearling coho salmon (Oncorhynchus kisutch). Can. J. Zool., 55:183198.

Nicoll, C.S. (1975) Radioimmunoassay and radioreceptor assays for prolactin and yrowth hormone: A critical appraisal. Am. Zool., 15:881-903.

Nicoll, C.S., S.W. Wilson, R.S. Nishioka, and H.A. Bern (1981) Blood and pituitary prolactin levels in Tilapia (Sarotherodon mossambicus; Teleostei) from different salinities as measured by a homologous radioimmunoassay. Gen. Comp. Endocrinol., 44:365-373.

Nishioka, R.S., H.A. Bern, K.V. Lai, Y. Nagahama, and E.G. Grau (1982) Change in the endocrine organs of coho salmon during normal and abnormal smoltification: An electron microscope study. Aquaculture, 28:21-38.

Oduleye, S.O. (1975) The effect of hypophysectomy and prolactin therapy on water balance of the brown trout Salmo trutta. J. Exp. Biol., 63:357-366.

Perry, S.F., and T.A. Heming (1981) Blood ionic and acidbase status in rainbow trout (Salmo gairdneri) following rapid transfer from fresh water to seawater: Effect of pseudobranch denervation. Can. J. Zool., 59:11261132.

Pickford, G.E., and J.G. Philips (1959) Prolactin-a factor in promoting survival of hypophysectomized killifish in fresh water. Science, 130:454-455.

Prunet P., and L.M. Houdebine (1984) Purification and biological characterization of chinook salmon prolactin. Gen. Comp. Endocrinol., 53:49-57.

Prunet, P., and G. Boeuf (1985) Plasma prolactin level during transfer of rainbow trout (Salmo gairdneri) and atlantic salmon (Salmo salar) from fresh water to seawater. Aquaculture, 45

Specker, J.L., P.M. Ingleton, and H.A. Bern (1984) Comparative physiology of prolactin cells. In: Frontiers and Perspectives in Prolactin Secretion: A Multidisciplinary Approach. F. Mena and C.M. Valverde, eds. Academic Press, New York. 